\title{
Efficacy of Organic Selenium from Se-Enriched Yeast on Selenium Transfer from Sows to Piglets
}

\author{
M. SVOBODA, R. FICEK, J. DRÁBEK
}

Clinic of Pig Diseases, Faculty of Veterinary Medicine, University of Veterinary and Pharmaceutical Sciences, Brno, Czech Republic

Received April 10, 2008

Accepted June 11, 2008

\begin{abstract}
Svoboda M., R. Ficek, J. Drábek: Efficacy of Organic Selenium from Se-Enriched Yeast on Selenium Transfer from Sows to Piglets. Acta Vet. Brno 2008, 77: 515-521.

The aim of the trial was to determine the efficacy of organic Se from Se-enriched yeast in placental transfer to piglets in the conditions of a Czech pig farm. In group I $(n=8)$ the sows were fed during gestation and lactation a diet supplemented with inorganic Se (sodium selenite, 0.3 $\mathrm{mg} / \mathrm{kg}$ of Se for the gestation and $0.38 \mathrm{mg} / \mathrm{kg}$ of Se for the lactation diet). In group II $(\mathrm{n}=8)$ the diet of the sows was supplemented with organic Se from Se-enriched yeast $(0.3 \mathrm{mg} / \mathrm{kg}$ of Se for the gestation and $0.38 \mathrm{mg} / \mathrm{kg}$ of Se for the lactation diet). Se concentrations in the whole blood, colostrum and milk were higher $(P<0.01)$ in the group of sows fed with the organic Se form. No differences in GSH-Px activities in the whole blood were found between the two groups of sows. The concentrations of Se in piglet tissues (heart $P<0.05$, liver $P>0.01$, muscle $P>0.01$ ) were also higher when the organic form was provided. It is concluded that the use of the organic Se from Se-enriched yeast in sows resulted in greater transfer of Se to their progeny, however it did not have a positive effect on the antioxidant system of the organism.
\end{abstract}

Inorganic selenium, glutathione peroxidase, colostrum, milk

For swine, selenium is an essential nutrient. It is principally available to the young pig from both placental and mammary transfer (Mahan et al. 1977). Selenium is an important component of the enzyme glutathione peroxidase (Tappel 1974). Several studies have demonstrated that the selenium status of pigs at birth can be affected by dietary Se concentration and the source of Se (Mahan et al. 1974; Mahan 2000; Mahan and Peters 2004). It has been shown that the Se content in newborn piglet tissues and sow colostrum was higher when organic vs. inorganic Se was fed (Mahan and Kim 1996). The sows fed organic Se had also a higher Se status than sows fed inorganic Se (Mahan 1994). Also studies performed on growing-finishing pigs (Mateo et al. 2007) demonstrated that the inorganic Se was not as effective in accumulating $\mathrm{Se}$ in tissues as organic Se.

Organic Se from Se-enriched yeast was used in our study. Selenium from Se-enriched yeast has a high bioavailability which can be explained by the composition of seleno-amino-acid analogues, the major one being selenomethionine (Schrauzer 2000). Selenomethionine (Se-Met) can be incorporated directly into body proteins in place of methionine (Me), because tRNA Met does not discriminate between Me and Se-Met (McConnell and Hoffman 1972).

The use of Se-enriched yeast has been documented mainly by North American authors (Mahan et al.1975; Mahan et al. 1977; Mahan and Peters 2004; Yoon and McMillan 2006). However, conditions that can influence the need and utilisation of Se in swine are different in the Czech Republic (breeds of sows, their reproductive performance, growth intensity of piglets, composition of diets, strain of Se-enriched yeast). Therefore, we decided to undertake a trial in order to evaluate the efficacy of organic Se in sows and their progeny under the conditions of a Czech pig farm.

Address for correspondence:

MVDr. Martin Svoboda, Ph. D.

University of Veterinary and Pharmaceutical Sciences

Palackého 1-3, 61242 Brno

Czech Republic
Phone: +420541562433

Fax: + 4205748841

E-mail: svobodama@vfu.cz

http://www.vfu.cz/acta-vet/actavet.htm 


\section{Materials and Methods}

Experimental conditions

A total of 16 pregnant third parity sows (Landrace $\times$ Czech Large White) were used in our study. The sows were divided into two groups and fed gestation and lactation diets composed of the basal diet and different forms of Se supplements. The basal diet contained $0.085 \mathrm{mg} / \mathrm{kg}$ of Se in case of the gestation diet, and $0.057 \mathrm{mg} / \mathrm{kg} \mathrm{of}$ Se in case of the lactation diet.

Group I ( 8 sows) received a feed mixture supplemented with inorganic Se (as sodium selenite, $0.3 \mathrm{mg} / \mathrm{kg}$ of Se for the gestation and $0.38 \mathrm{mg}$ of Se for the lactation diet).

Group II (8 sows) had gestation and lactation diets supplemented with organic selenium in the form of Seenriched yeast $(0.3 \mathrm{mg} / \mathrm{kg}$ of Se for the gestation and $0.38 \mathrm{mg}$ of Se for the lactation diet).

The Se from Se-enriched yeast Sel-Plex (Alltechnology CZ s.r.o) was used in our study. Gestation diet was provided at $2.5 \mathrm{~kg}$ daily during the gestation period. Sows were fed ad libitum during the lactation period. Compositions of gestation and lactation diets are presented in Tables 1 and 2.

Table 1. Percentage composition of the gestation diet

\begin{tabular}{|l|c|}
\hline Ingredient & Percentage \\
\hline Barley & 42 \\
\hline Corn & 17 \\
\hline Wheat & 15 \\
\hline Wheat pollard & 5 \\
\hline Soybean pollard & 5.8 \\
\hline Soybean oil & 0.2 \\
\hline Oat & 10 \\
\hline Trace mineral and vitamin premix & a \\
\hline
\end{tabular}

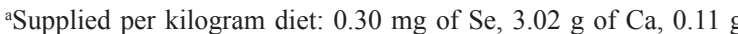
of K, $3.33 \mathrm{~g}$ of $\mathrm{Cl}, 0.08 \mathrm{~g}$ of $\mathrm{Mg}, 36.64 \mathrm{mg}$ of $\mathrm{Mn}, 83.72 \mathrm{mg}$ of $\mathrm{Fe}, 12.07 \mathrm{mg}$ of $\mathrm{Cu}, 0.54 \mathrm{mg}$ of Co, $97.37 \mathrm{mg}$ of $\mathrm{Zn}, 1.11 \mathrm{mg}$ of J, 12149.99 I.U. of vit. A, 1800.00 I.U. of vit. D3, $49.72 \mathrm{mg}$ of vit. $\mathrm{E}, 1.89 \mathrm{mg}$ of vit. K3, $4.07 \mathrm{mg}$ of vit. B1, $6.87 \mathrm{mg}$ of vit. B2, 5.63 $\mathrm{mg}$ of vit. B6, $45.02 \mu \mathrm{g}$ of vit. B12, $18.47 \mathrm{mg}$ of niacin, $20.84 \mathrm{mg}$ of panthotenic acid, $0.19 \mathrm{mg}$ of biotin, $0.37 \mathrm{mg}$ of folic acid, 54.57 mg of cholin

Table 2. Percentage composition of the lactation diet

\begin{tabular}{|l|c|}
\hline Ingredient & Percentage \\
\hline Barley & 25 \\
\hline Corn & 23.5 \\
\hline Wheat & 24.2 \\
\hline Soybean pollard & 20.8 \\
\hline Yeast Vitex & 0.3 \\
\hline Soybean oil & 1.2 \\
\hline Trace mineral and vitamin premix ${ }^{\mathrm{a}}$ & 5 \\
\hline
\end{tabular}

aSupplied per kilogram diet: $0.38 \mathrm{mg}$ of Se, $8.11 \mathrm{~g}$ of Ca, $3.00 \mathrm{~g}$ of $\mathrm{P}, 1.95 \mathrm{~g}$ of $\mathrm{Na}, 0.18 \mathrm{~g}$ of $\mathrm{K}, 3.26 \mathrm{~g}$ of $\mathrm{Cl}, 0.10 \mathrm{~g}$ of $\mathrm{Mg}, 44.38 \mathrm{mg}$ of $\mathrm{Mn}, 103.37 \mathrm{mg}$ of Fe, $15.11 \mathrm{mg}$ of $\mathrm{Cu}, 0.69 \mathrm{mg}$ of Co, 122.50 $\mathrm{mg}$ of $\mathrm{Zn}, 0.87 \mathrm{mg}$ of J, 14174.99 I.U. of vit. A, 2100.00 I.U. of vit D3, $57.82 \mathrm{mg}$ of vit. E, $2.21 \mathrm{mg}$ of vit. K3, $4.69 \mathrm{mg}$ of vit. B1, 8.33 $\mathrm{mg}$ of vit. B2, $6.65 \mathrm{mg}$ of vit. B6, $52.90 \mu \mathrm{g}$ of vit. B12, $25.71 \mathrm{mg}$ of niacin, $24.65 \mathrm{mg}$ of pantotenic acid, $0.24 \mathrm{mg}$ of biotin, $0.62 \mathrm{mg}$ of folic acid, $170.50 \mathrm{mg}$ of cholin

Commitee of the University of Veterinary and Pharmaceutical Sciences, Brno, Czech Republic.

At the age of 3 days the piglets were injected i.m. with $200 \mathrm{mg}$ of Fe (iron dextran, Ferridextran 10\% Spofa).

Sampling and analysis

Colostrum was collected by hand expression from several glands. Milk was obtained on day 14 after i.v. injection (5 i.u.) of oxytocin. The collected colostrum and milk was frozen and stored for later determination of Se content.

Two neonatal piglets from each litter were randomly selected, killed prior to colostrum consumption and tissue samples were collected (liver, heart, gluteal muscles).

On days 3 and 14 the sows and piglets were blood-sampled from anterior vena cava. The sows were bled also on day 1 and on day 60 of gestation.

Concentrations of Se in the colostrum, whole blood and piglet tissues (heart, liver, gluteal muscles) were measured using the following steps: samples of the whole heparinised blood were mineralised in a closed system using a microwave (MLS-1200, Milestone, Italy) digestion technique with $\mathrm{HNO}_{3}$ and $\mathrm{H}_{2} \mathrm{O}_{2}$. Samples were evaporated and the mineral residue was dissolved in water to which $20 \% \mathrm{HCl}$ was added. Selenium was then determined with Solar 939 AA Spectrometer (Unicam, UK) using a hydride AAS technique.

Whole blood glutathione peroxidase (GSH-Px) activities were determined according to the method of Paglia and Valentin (1967) using the test kit RANSEL (Randox Laboratories, Ltd., United Kingdom).

Statistical analyses

The results were evaluated statistically by Student's $t$-test.

The experiment was approved by Ethics

\section{Results}

The results are presented as mean and standard deviation of each index in Table 3 and in Figs $1-6$. In all figures values with $*(P<0.05)$ and $* *(P<0.01)$ express significant 
Table 3. Reproductive performance

\begin{tabular}{|l|c|c|}
\hline Item & $\begin{array}{c}\text { Group I } \\
\text { Mean } \pm \text { SD }\end{array}$ & $\begin{array}{c}\text { Group II } \\
\text { Mean } \pm \text { SD }\end{array}$ \\
\hline Total number of piglets born & $12.50 \pm 1.89$ & $11.25 \pm 2.38$ \\
\hline Number of live piglets born & $11.17 \pm 1.77$ & $10.50 \pm 2.06$ \\
\hline Number of stillborn piglets & $1.33 \pm 0.94$ & $0.75 \pm 0.83$ \\
\hline Piglet birth weights & $1.37 \pm 0.25$ & $1.43 \pm 0.34$ \\
\hline Piglet weights at the age of 14 days & $4.13 \pm 0.74$ & $4.44 \pm 0.86$ \\
\hline
\end{tabular}

The number of piglets born (total, live, stillborn) was not affected by the form of Se supplen. (organic vs. inorganic).

Selenium status of the sows

Indices of the selenium status of the sows are presented in Figs 1-2. No differences in indices of the selenium status were found between the two groups at the beginning of the experiment (day 1 of gestation).The Se concentrations in the whole blood were higher in the group of sows fed Se from Se-enriched yeast than in inorganic group on day 60 of gestation and 3 and 14 days after parturition $(P<0.01)$.

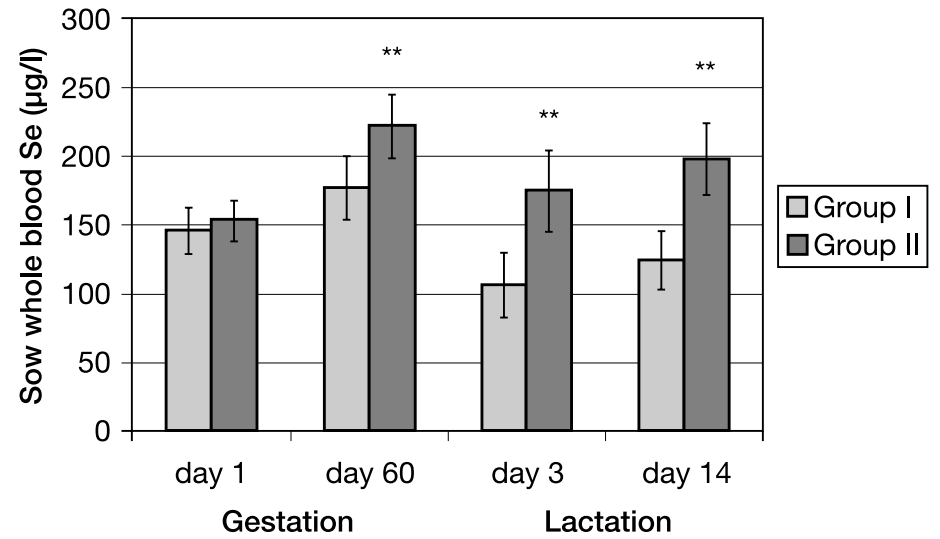

Fig. 1. Concentration of Se in the whole blood of sows

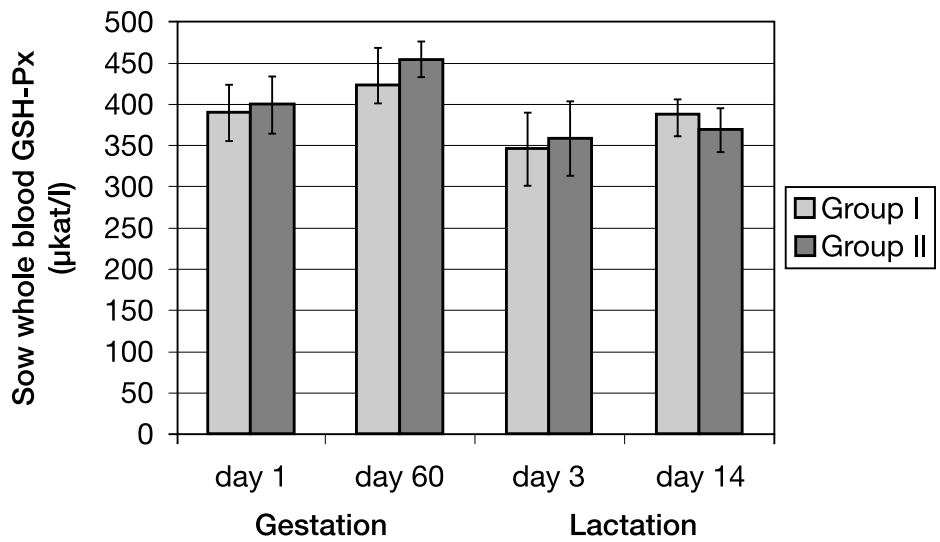

Fig. 2. GSH-Px activities in the whole blood of sows 
GSH-Px activities of the whole blood were comparable for both organic and inorganic Se at each measurement period.

Colostrum and milk selenium

The results are presented in Fig. 3. The use of Se from Se-enriched yeast resulted in a significantly higher Se concentration in the colostrum $(P<0.01)$ and in milk $(P<0.01$, 14 days after parturition) compared to sows fed the inorganic form.

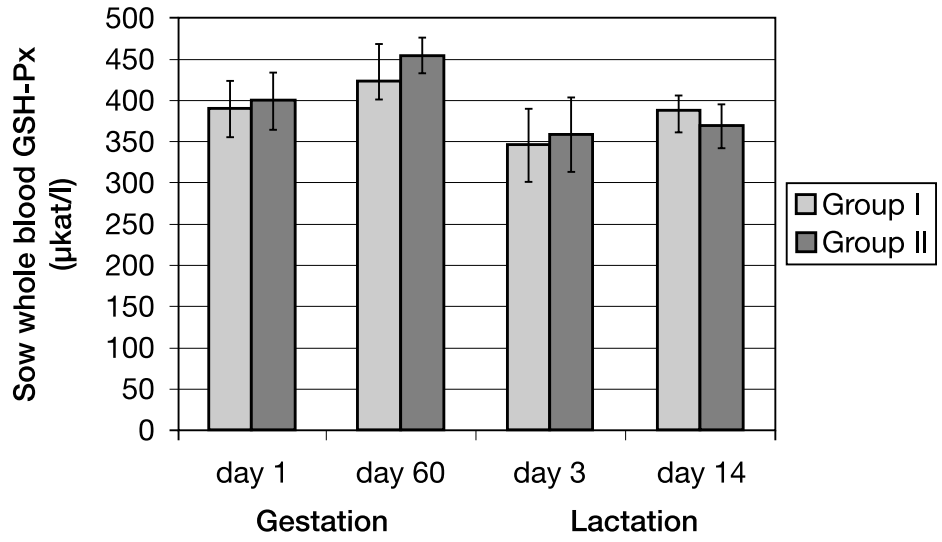

Fig.3. Concentration of Se in colostrum and milk

Selenium status of the piglets

The results of the selenium status of the piglets are presented in Figs 4-6. The concentrations of Se in neonatal tissues (liver, heart, gluteal muscles) were significantly higher when organic Se was fed (liver, muscle, $P<0.01$; heart, $P<0.05$ ). Se concentrations in the whole blood at the age of 3 and 14 days were higher when organic Se from Se-enriched yeast was provided to the sows (both, $P<0.01$ ). GSH-Px activities of the whole blood were comparable for both organic and inorganic Se at each measurement period.

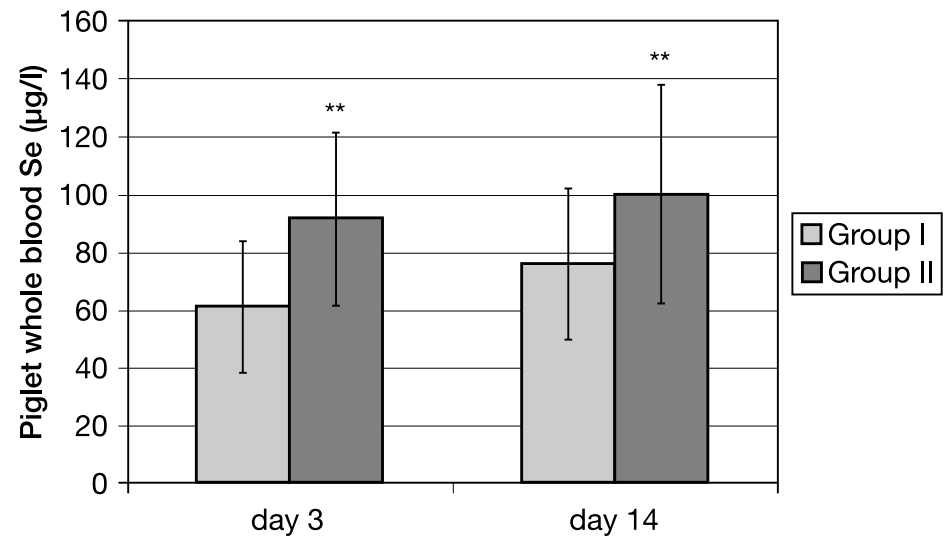

Fig. 4. Concentration of Se in the whole blood of piglets 


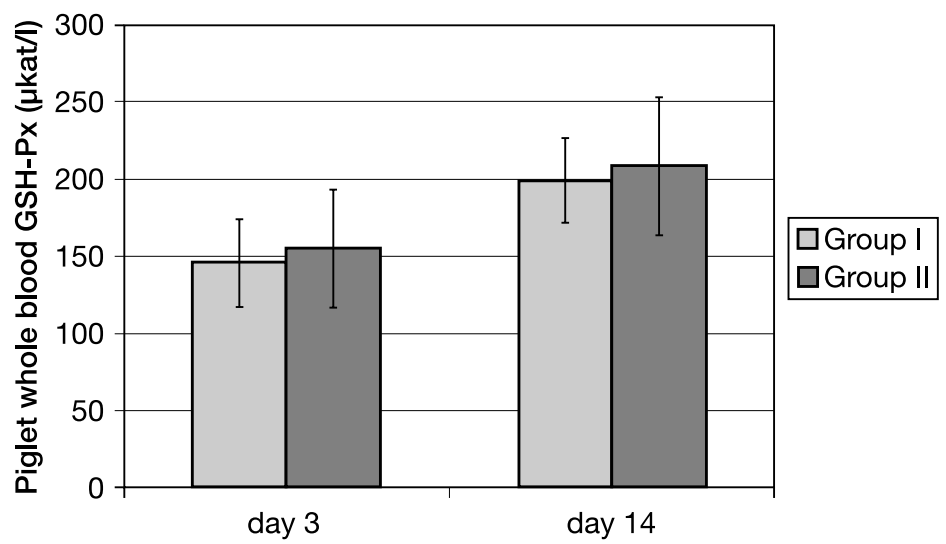

Fig. 5. GSH-Px activities in the whole blood of piglets

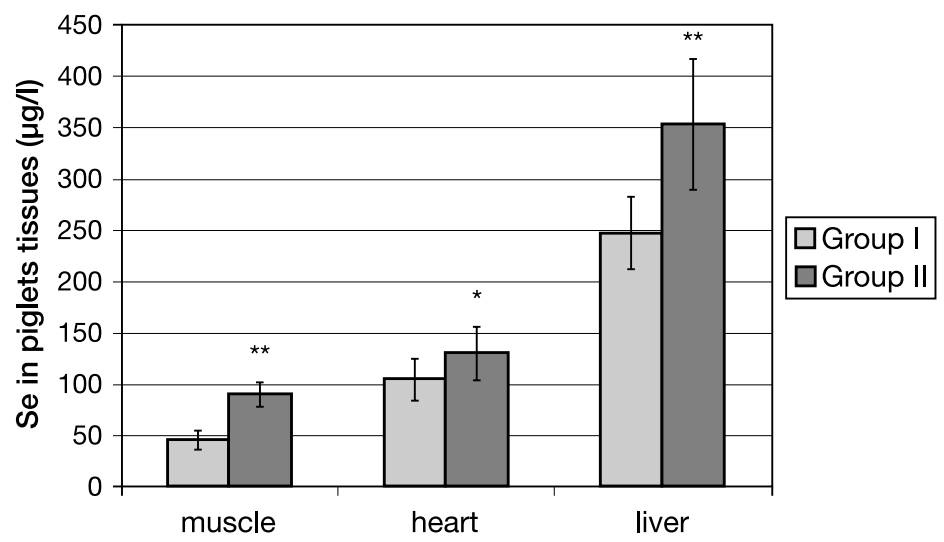

Fig. 6. Concentration of Se in piglet tissues

\section{Discussion}

Comparing our findings with other authors, we find that there are many differences among various experimental studies.

In our study we have found a higher concentration of Se in the colostrum and milk in the group of sows fed organic Se. This is in agreement with the studies of Mahan (2000) and Yoon and McMillan (2006) where both colostrum and milk Se concentrations were found to be higher when organic Se was fed. On the other hand, Mahan and Kim (1996) reported that the colostrum Se content was unaffected by the Se source but milk Se increased when organic Se was fed. In another study the milk Se content was $80 \%$ higher in the organic Se group than when selenite was fed (Mahan and Kim 1996). Much higher difference was found in the study of Mahan (2000) where the Se content in milk was 2.5-3 times higher when the organic source was fed.

We have found that Se concentrations in the whole blood of sows fed Se from Se-enriched yeast were superior to the inorganic form. This corresponds with the findings of Mahan and Peters (2004) who reported higher Se concentrations in a group of sows fed Se from Se-enriched yeast. 
GSH-Px activities of the whole blood in sows and piglets did not differ between groups. This is in agreement with Mahan and Peters (2004) and Yoon and McMillan (2006) who found that both Se from Se-enriched yeast and inorganic form are adequate for the synthesis of GSH-Px.

Mahan and Peters (2004) reported that the total body Se content in the neonate was approximately doubled when organic Se was provided to sows. In our study we have also found higher Se concentrations in neonatal tissues, but the difference was less pronounced. The less pronounced difference was shown also by Mahan and Kim (1996).

The differences among authors may be caused by several factors. In our study we used crossbred sows (Landrace $\times$ Czech Large White). The effect of different genotypes on Se requirements has not yet been firmly established. For instance, Kim and Mahan (2001) reported that white-haired pigs exhibit selenosis more rapidly than red or black-haired pigs. The authors suggest that Se deposition in the tissues of more muscular breeds may differ, since muscles retain Se. Mahan and Newton (1995) suggest that depletion of Se reserves is exacerbated with the increasing productivity of sows. Stowe and Miller (1985) support the hypothesis that some pigs have an impaired, perhaps genetically influenced ability to utilise dietary Se. Possible genetic differences in the blood GSH-Px among breeds were suggested by Jorgensen et al. (1977).

Utilisation of Se could be influenced also by the composition of seleno-amino-acid analogues in Se-enriched yeast used in various experimental studies. According to Mahan and Parrett (1996) more than $70 \%$ of Se in Se-enriched yeast is in the form of selenomethionine. Schrauzer (2000) reported that Se-enriched yeast contained SeMet $(90 \%$ of the total Se) and additional organoselenium compouds (selenocystein, methylselenocystein, selenocystathionine). On the other hand, Kelly and Power (1995) found that a Se-enriched yeast strain contained $40 \%$ of selenomethionine, $15 \%$ of selenocysteine and lower percentage of other seleno-amino-acid analogues. The yeast strain used in our study contained $97-99 \%$ of organic Se of which $63-66 \%$ was in the form of selenomethionine (information provided by Alltechnology $\mathrm{CZ}$ s.r.o.).

The results are influenced also by the concentration of Se used. The findings of Mahan and Peters (2004) show that, both Se forms are adequate for the synthesis of GSH-Px of sows at the dose of $0.15 \mathrm{ppm}$. However, an increase to $0.3 \mathrm{ppm}$ Se results in greater Se concentration in the neonates, colostrum and milk.

Se metabolism is also influenced by parities. As parities progress, sow milk Se concentration decreases when inorganic Se is fed (Mahan et al. 1991, 1994). In contrast, the Se content of the milk of sows fed the organic source remains constant between parities (Mahan and Peters 2004).

In our study we have found that the reproductive performance of sows was similar in both Se sources, but sows fed organic Se had a greater transfer of Se to piglets, colostrum and milk. It is concluded that under the conditions of Czech pig farms, organic Se from Se-enriched yeast is more effective in accumulation in tissues than the inorganic form. We suggest that the evaluation of the efficiency of organic Se products be based on particular conditions of swine herds.

\section{Účinnost organického selenu ze selenem obohacených kvasnic v transplacentárním přenosu na selata}

Cílem studie bylo zjistit účinnost organicky vázaného selenu ze selenem obohacených kvasnic $\mathrm{v}$ placentárním přenosu na selata v podmínkách České republiky. Ve skupině I $(\mathrm{n}=8)$ dostávaly prasnice během březosti a laktace krmivo suplementované anorganicky vázaným selenem (seleničitan sodný, $0,3 \mathrm{mg} / \mathrm{kg}$ Se v krmivu pro březí prasnice, $0,38 \mathrm{mg}$ / kg Se v krmivu pro kojící prasnice). Ve skupině II $(\mathrm{n}=8)$ bylo krmivo suplementováno organicky vázaným selenem ze selenem obohacených kvasnic $(0,3 \mathrm{mg} / \mathrm{kg} \mathrm{Se} v \mathrm{krmivu}$ pro 
březí prasnice, $0,38 \mathrm{mg} / \mathrm{kg}$ Se v krmivu pro kojící prasnice). Koncentrace selenu v plné krvi, v kolostru a mléce byly vyšší $(P<0.01)$ ve skupině prasnic krmených organickou formou selenu. Mezi oběma skupinami nebyly zjištěny rozdíly v aktivitě GSH-Px v plné krvi. Koncentrace selenu v tkáních selat (srdce $P<0.05$, játra $P<0.01$, svalovina $P<0.01$ ) byly také vyšší v př́ípadě použití organické formy. Žádné rozdíly nebyly zjištěny v aktivitě GSH-Px u selat. Závěrem lze konstatovat, že použití organického selenu ze selenem obohacených kvasnic u prasnic mělo za následek větší transfer selenu na potomstvo, ačkoliv nebyl prokázán pozitivní vliv na antioxidační systém organizmu.

\section{Acknowledgement}

The study was supported by the project MSM 6215712403.

\section{References}

JORGENSEN PF, HYLDGAARD-JENSEN J, MOUSTGAARD J 1977: Glutathione peroxidase activity in porcine blood. Acta Vet Scand 18: 323-334

KELLY MP, POWER RF 1995: Fractionation and identification of the major selenium compounds in selenized yeast. J Dairy Sci 78 (Suppl.): 237

KIM YY, MAHAN DC 2001: Effect of dietary selenium source, level, and pig hair color on various selenium indices. J Anim Sci 79: 949-955

MAHAN DC 1991: Assessment of the influence of dietary vitamin E on sows and offspring in three parities: reproductive performance, tissue tocopherol, and effects on progeny. J Anim Sci 69: 2904-2917

MAHAN DC 1994: Effects of dietary vitamin E on sow reproductive performance over a five-parity period. J Anim Sci 72: 2870-2879

MAHAN DC 2000: Effect of organic and inorganic selenium sources and levels on sow colostrum and milk selenium content. J Anim Sci 78: 100-105

MAHAN DC, KIM YY 1996: Effect of inorganic or organic selenium at two dietary levels on reproductive performance and tissue selenium concentrations in first-parity gilts and their progeny. J Anim Sci 74: 2711-2718

MAHAN DC, MOXON AL, CLINE JH 1975: Efficacy of supplemental selenium in reproductive diets on sow and progeny serum and tissue selenium values. J Anim Sci 40: 624-631

MAHAN DC, MOXON AL, HUBBARD M 1977: Efficacy of inorganic selenium supplementation to sow diets on resulting carry-over to their progeny. J Anim Sci 45: 738-746

MAHAN DC, NEWTON EA 1995: Effect of initial breeding weight on macro- and micro-mineral composition over a three parity period using a high-producing sow genotype. J Anim Sci 73: 151-158

MAHAN DC, PARRETT NA 1996: Evaluating the efficacy of selenium-enriched yeast and sodium selenite on tissue selenium retention and serum glutathione peroxidase activity in grower and finisher swine. J Anim Sci 74: $2967-2974$

MAHAN DC, PENHALE LH, CLINE JH, MOXON AL, FETTER AW, YARRINGTON JT 1974: Efficacy of supplemental selenium in reproductive diets on sow and progeny performance. J Anim Sci 39: 536-543

MAHAN DC, PETERS JC 2004: Long-term effects dietary organic and inorganic selenium sources and levels on reproducing sows and their progeny. J Anim Sci 82: 1343-1358

MATEO RD, SPALLHOLZ JE, ELDER R, YOON I, KIM SW 2007: Efficacy of dietary selenium source on growth and carcass characteristics of growing-finishing pigs fed diets containing high endogenous selenium. J Anim Sci 85: 1177-1183

MCCONNELL KP, HOFFMAN JL 1972: Methionine-selenomethionine parallels in rat liver polypeptide chain synthesis. FEBS Lett 24: 60-62

SCHRAUZER GN 2000: Selenomethionine: a review of its nutritional significance, metabolism and toxicity. J Nutr 130: 1653-1656

STOWE HD, MILLER ER 1985: Genetic predisposition of pigs to hypo-and hyperselenemia. J Anim Sci 60: $200-211$

TAPPEL AL 1974: Selenium-glutathione peroxidase and vitamin E. Am J Clin Nutr 27: 960-965

YOON I, MCMILLAN E 2006: Comparative effects of organic and inorganic selenium on selenium transfer from sows to nursing pigs. J Anim Sci 84: 1729-1733 
